\title{
Academic Information Systems and Recommendations using AHP at SMA Islamic Center Tangerang
}

\author{
Alvira Putri Yudini ${ }^{1}$, Calandra Alencia Haryani ${ }^{2}$, Andree E. Widjaja ${ }^{3}$, Hery $^{4}$, Suryasari $^{5}$ \\ 1,2,3,4 Information Systems, Universitas Pelita Harapan, Tangerang, Indonesia \\ ${ }^{5}$ Department of Informatics, Multimedia Nusantara University, Tangerang, Indonesia \\ 1ªlvirap7@gmail.com, ${ }^{2}$ calandra.haryani@uph.edu, ${ }^{3}$ andree.widjaja@uph.edu, ${ }^{4}$ hery.fik@uph.edu, \\ ${ }^{5}$ suryasari@umn.ac.id
}

Accepted 24 October 2021

Approved 4 January 2022

\begin{abstract}
Nowadays, technology is indispensable to solve problems. Technology can facilitate communication without thinking about distance, space, and time. Currently, the advancement of technology is useful for most people in carrying out their activities, especially in the field of education. Islamic Centre High School Tangerang is one of the schools that require information systems to manage data as it still uses the manual method.

This research was specifically conducted to assist $t$ Islamic Centre High School Tangerang in building a system for managing school data, so that it can provide recommendations to students to decide on a study program to a higher level of education, as well as to help parents monitoring their children activities. The methodology used in this study is qualitative methods, RAD methodology and the Prototyping method. Meanwhile, the method of recommending study programs for students used the Analytical Hierarchy Process method, that is by comparing the value of criteria consisting of accreditation, majors, grades, and comparison of alternative values consisting of study programs and universities. The system was tested using black box testing method. The result of this study is a web-based academic information systems with recommendation feature. The system can display a ranking of student study program recommendations based on a comparison of criteria and alternative values using the Analytical Hierarchy Process Method.
\end{abstract}

Index Terms- Recommendation, Academic Information System, Analytical Hierarchy Process (AHP), prototyping

\section{INTRODUCTION}

Technology can be used as a tool to solve a problem or as a communication tool [1]. The use of technology provides convenience, such as processing data, sharing information and doing business. Most of the technology has been widely used in the fields of business, entertainment, industry, communication, and education. When technology has not developed as it is today, all activities are done manually, in so doing activities become slow and thus require a lot of time. Education is one of the fields that require technology. Current technological advancements in education field are expected to assist educators in providing convenience in managing data [2][3]. Therefore, with the development of current technology, it is very helpful for most humans in carrying out their activities, especially in the field of education which requires an accurate information system to minimize errors [4], hence information systems are needed [5].

Information systems used in the field of education are called academic information systems. Academic information system is software used to present information and organize administration related to academic activities [6]. The services provided are as follows: management of student data, schedules, grades, and report cards. An educational institution is a place where the teaching and learning process takes place, including education in the family, school, and community. In the current era of globalization, educational institutions will be able to apply information technology to support academic activities such as data processing and presenting academic information quickly and accurately, but there are still some schools that use manual methods in presenting information [7][8].

This is mainly due to the lack of qualified teachers in the IT field. Based on the Central Statistics Agency which has conducted a survey in 4,014 schools spread across 34 provinces, there are results that the use and utilization of information and communication technology for the proportion of teachers who have qualifications in the IT field at the high school level 
and the equivalent is $14.43 \%$ [9]. One of the educational institutions that still uses manual methods in managing their data is Islamic Center High School Tangerang. Currently, they still use manual methods in carrying out academic activities such as taking attendance using paper, using grade books to store student grades, calculating them manually by asking each category weight to the respective subject teacher, calculating it and then entering it into the report card. Based on interviewed with headmaster, there are frequent errors in the calculation of grades and there are some students who complain because of the incorrect spelling of names on the report card because of manual tasking. So, an academic information system is purposefully created to assist SMA Islamic Center Tangerang in processing academic data properly.

The result can help SMA Islamic Center Tangerang to managing student and teacher data, viewing class schedules, viewing grades, downloading test cards, and printing student report cards. The required academic information system using Analytical Hierarchy Process (AHP) method can also help students in class $\mathrm{X}$ and $\mathrm{XI}$ to get recommendation for the study program they are interested in or want when they go to a higher level of education. AHP method used for this research because this method can give teacher privilege to manage category weight based on their preference for personalization recommendation study program result.

\section{METHOD}

The system development methodology used for the Academic Information System is the Rapid Application Development (RAD) using prototyping method. RAD is a development method a system in a relatively short time. Advantages obtained with using the RAD methodology is faster, more accurate, and more cost-effective inexpensive [10]. The Prototyping method is a system model that help development is done quickly and easily. The Prototyping method provides how to develop a more effective and efficient system through discussion, exploration, experimentation, and improvement over and over again [10]. The recommendation system for this webiste is using Analytical Hierarchy Process (AHP). The AHP was first developed and introduced in 1970 by Thomas L. Saaty, a Professor of Mathematics from the University of Pittsburgh [11]. AHP is one of the methods of Multi-Criteria Decision Making (MCDM). AHP is a measurement theory used to derive ratio scales from discrete and continuous pairwise comparisons [1] [11][12].

The AHP method is carried out by forming a problem structure and then compiling a hierarchical structure of the problem starting from the goal, then the criterion variable, then followed by alternative variables. The AHP method is widely used to prioritize options with many criteria, but its application has been widely used as an alternative model of cost benefits, forecasting and others [13]. In the field of education, the AHP method can help in making decisions about choosing a study program [14].

In solving problems with the AHP method, there are several basic principles, namely, decomposition (principles of compiling a hierarchy), comparative judgment, synthesis of priority, logical consistency $[15][16][17]$. The first step in determining the priority of elements in a decision problem is to make pairwise comparisons. The AHP method uses pairwise comparison between one factor and other factor to produce factor weights and between one alternative to another alternative for evaluation factor. The factor uses pairwise comparison matrix as with 1-9 scale [1]. The elements are compared in pairs against a specified criterion. Table 1 pairwise comparison presented in the form of a matrix.

TABLE I. IS THE SCALE USED TO FILL IN THE PAIRWISE COMPARISON MATRIX

\begin{tabular}{|c|l|}
\hline $\begin{array}{c}\text { Level Of } \\
\text { Importance }\end{array}$ & \multicolumn{1}{c|}{ Definition } \\
\hline 1 & Equality Important \\
\hline 3 & Moderately More Important \\
\hline 5 & Slightly More Important \\
\hline 7 & Very Strongly More Important \\
\hline 9 & Extremely More Important \\
\hline $2,4,6,8$ & $\begin{array}{l}\text { Neutral value between slightly more important } \\
\text { and more important }\end{array}$ \\
\hline
\end{tabular}

The pairwise comparison matrix can be normalized with the following steps [18]:

1. Add up the values of each column of the pairwise comparison matrix: $\sum_{i=1}^{n} a_{i j}$ for $i, j=1,2, \ldots, n$

2. Divide the value $a_{i j}$ in each column by the sum of the values in the column: $a_{i j}=\frac{a_{i j}}{\sum_{i=1}^{n} a_{i j}}$ for $i, j=$ $1,2, \ldots, n$.

3. Add up all the values of each row of the normalized matrix and divide by the elements of each row. The result of the division shows the priority value for each element.

Inconsistency often occurs in pairwise comparison assessments. The consistency of the paired assessment was evaluated by calculating the Consistency Ratio (CR). When determining if $\mathrm{CR}=0.1$ then the results of the assessment are said to be consistent. The formulation to calculate the Consistency Ratio is as follows:

$$
C R=\frac{C I}{R I}
$$

Description:

CI = Consistency Index 


\section{ISSN 2085-4552}

RI = Random Consistency Index

The formula for calculating CI is as follows:

$$
C I=\frac{\left(\lambda_{\max }-n\right)}{n-1}
$$

Description:

$\lambda_{\max }=$ the maximum value of the eigenvalues of order $\mathrm{n}$.

The maximum eigen value is obtained by adding up the result of the comparison matrix multiplication with the main eigenvector (priority vector) and dividing it by the number of elements. The CI value will be meaningless if there is no reference to state whether the CI shows a consistent or inconsistent matrix.

\begin{tabular}{|c|c|c|c|c|c|c|c|c|c|c|c|c|}
\hline $\begin{array}{c}\text { Ordo } \\
\text { Matriks }\end{array}$ & 1,2 & 3 & 4 & 5 & 6 & 7 & 8 & 9 & 10 & 11 & 12 & 13 \\
\hline $\mathrm{RI}$ & 0 & 0,52 & 0,89 & 1,11 & 1,25 & 1,35 & 1,4 & 1,45 & 1,49 & 1,51 & 1,54 & 1,56 \\
\hline
\end{tabular}

Fig. 1.Random Index (RI) value obtained by Saaty.

Any scalar multiple $\mathrm{kv}$ of the eigenvector $\mathrm{v}$ that includes $\lambda$ is also an eigenvector because:

$$
A(k v)=k(A v)=k(\lambda v)=\lambda(k v)
$$

To achieve the eigenvalues of the matrix $A$ of size $n \times n$. then it can be written in the following equation:

$$
A v=\lambda v
$$

Or equivalently:

$$
(\lambda I-A) v=0
$$

For $\lambda$ to be an eigenvalue, there must be a non-zero solution of the above equation. However, the above equation will have a non-zero solution if and only if:

$$
\operatorname{det}(\lambda I-A) v=0
$$

The above equation is called the characteristic equation $\mathrm{A}$, the scalar that satisfies the above equation is the eigenvalue of $\mathrm{A}$. It is known that the value of the ratio of element $A_{i}$ to element $A_{j}$ is $a_{i j}$, so theoretically the matrix has the opposite positive characteristic, namely $a_{i j}=\frac{1}{a_{i j}}$. The weight sought is expressed in vector $w=\left(w_{1}, w_{2}, w_{3}, \ldots, w_{n}\right)$. The value of $w_{n}$ represents the weight of criterion $A_{n}$ against the entire set of criteria in the sub-system. If $a_{i j}$ represents the degree of importance of factor $i$ to factor $\mathrm{j}$ and $a_{i k}$ represents the degree of importance of factor $\mathrm{j}$ to factor $\mathrm{k}$ then for the decision to be consistent, the importance of factor $\mathrm{i}$ to factor $\mathrm{k}$ must be equal to $a_{i j} \cdot a_{j k}$ or if $a_{i j} \cdot a_{j k}=a_{i k}$ for all $\mathrm{i}, \mathrm{j}, \mathrm{k}$. For a matrix consistent with vector $\mathrm{w}$, then the element aij can be written:

$$
a_{i j}=\frac{w_{i}}{w_{j}} ; \forall i, j=1,2,3, \ldots, n
$$

So, the consistency matrix is as follows:

$$
a_{i j} \cdot a_{j k}=\frac{w_{i}}{w_{j}} \cdot \frac{w_{j}}{w_{k}}=\frac{w_{i}}{w_{k}}=a_{i k}
$$

As described above, the pairwise comparison matrix can be broken down into:

$$
a_{i j}=\frac{w_{i}}{w_{j}}=\frac{1}{w_{j} / w_{i}}=\frac{1}{a_{j i}}
$$

From the above equation, we get:

$$
a_{i j} \cdot \frac{w_{j}}{w_{i}}=1
$$

From the above equation, it can be seen that the consistent pairwise comparison matrix is:

$\sum_{i . j=1}^{n} a_{i j} \cdot a_{i j} \cdot \frac{1}{w_{i j}}=n ; \forall i, j=1,2,3, \ldots, n$

$\sum_{i . j=1}^{n} a_{i j} \cdot a_{i j}=n w_{i j} ; \forall i, j=1,2,3, \ldots, n$

The above equation is equivalent to the form of a matrix equation:

$$
A \cdot w=n \cdot w
$$

In matrix theory, the above formulation explains that $\mathrm{w}$ is the eigenvector of matrix A with the Eigen values of $n$. Note that $n$ is the dimension of the matrix itself. In the form of a matrix equation, it can be written as follows:

$$
\left[\begin{array}{cccc}
\frac{w_{1}}{w_{1}} & \frac{w_{1}}{w_{2}} \cdots & \frac{w_{1}}{w_{n}} \\
\frac{w_{2}}{w_{1}} & \frac{w_{2}}{w_{2}} \cdots & \frac{w_{2}}{w_{n}} \\
\vdots & \vdots & \ddots & \vdots \\
\frac{w_{n}}{w_{1}} & \frac{w_{n}}{w_{2}} \cdots & \frac{w_{n}}{w_{n}}
\end{array}\right]
$$

But in reality, it cannot be guaranteed that:

$$
a_{i j}=\frac{a_{i k}}{a_{j k}}
$$

One of the causes of this happening,, is the human element (decision maker) because it is not always consistent and absolute in expressing preferences for the elements being compared. In other words, the assessment given to each element of the problem at a hierarchical level may be inconsistent.

\section{RESULT AND DISCUSSION}

The following are the steps in calculating AHP: 


\section{A. Create a recommendation hierarchy}

The first step in calculating AHP is to create a hierarchy consisting of three levels, the first level of objectives, the second level of assessment criteria and the third level of alternative choices and assessments. The factor that determines the results of the recommendations is by determining the weights on the criteria and alternatives. The weight of the assessment is carried out first to create a pairwise comparison matrix that describes the effect of each criterion on the alternatives. Figure 2 is a hierarchy of recommendations for the "Information Academic Islamic Center High School” system.

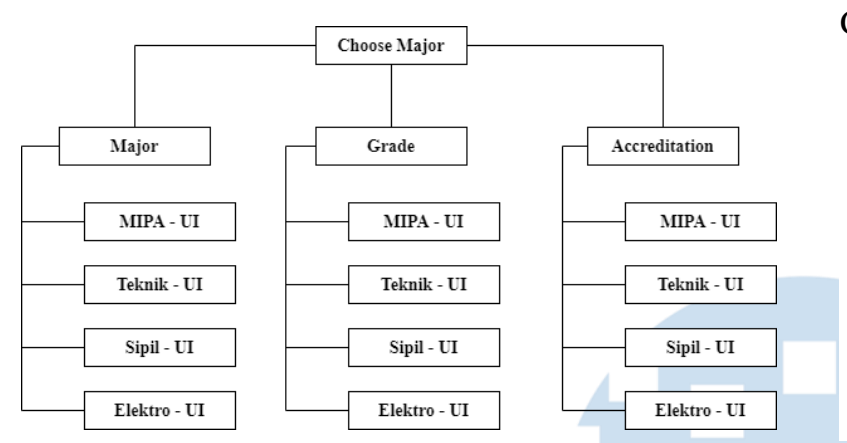

Fig. 2. Recommendation Hierarchy

The data in Figure 2 is the data entered by the user. Users can add their own criteria and alternatives. The criteria in Figure 2 were added based on the Ministry of Education and Culture's assessment for SNMPTN.

\section{B. Do pairwise comparisons}

After creating the hierarchy, the next step is to perform pairwise comparisons based on the Saaty scale to get the weight of the criteria. Table 2 is a pairwise comparison to get the weight of the criteria.

TABLE II. COMPARISON TABLE OF PAIRED CRITERIA

\begin{tabular}{|c|c|c|c|}
\hline & Grade & Accreditation & Major \\
\hline MAJORS & 1 & $1 / 2$ & 3 \\
\hline ACCREDITATION & 2 & 1 & 4 \\
\hline GRADE & $1 / 3$ & $1 / 4$ & 1 \\
\hline
\end{tabular}

\section{Performing the calculation of the weight of the} criteria

After performing pairwise comparisons, the next step is to calculate the weight of the criteria (priority vector). Figure 3 is the calculation of the weight of the criteria. The criterion matrix is obtained after doing a weight comparison, after that normalization of each matrix, according to the formula contained in the previously described equation. The results of the normalization of the matrix will be added every row, if you get the results, then the columns will be summed. The result of the sum will be calculated with the result of the column sum to get the average matrix.

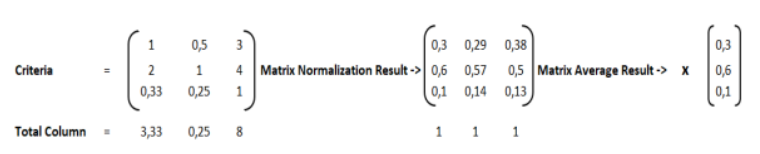

Fig. 3 Calculation of Criteria Weight

\section{Check Consistency Ratio (CR)}

The next step is to check the Consistency Ratio (CR) of the criterion paired comparison matrix. If CR $>0.1$, the pairwise comparison must be repeated until $\mathrm{CR}<=0.1$. Before calculating the $\mathrm{CR}$ value, it must be calculated to get the Consistency Index (CI) value. The CI formula can be found in the previously described equation. Figure 4 is a calculation to get the CI value.

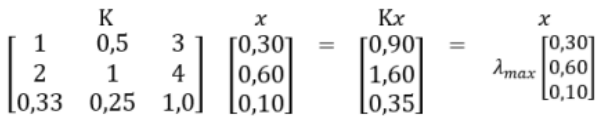

$$
\begin{aligned}
& \lambda_{\max }=\text { average }\left\{\left(\frac{0,90}{0,30}\right),\left(\frac{1,60}{0,60}\right),\left(\frac{0,35}{0,10}\right)\right\}=3,06 \\
& C I=\frac{\left(\lambda_{\max }-n\right)}{n-1}=\frac{(3,06-3)}{3-1}=0,03
\end{aligned}
$$

Fig. 4. Calculation of CI

After getting the CI value contained in Figure 4, you can directly perform calculations to get the CR value. Figure 5 is a calculation to get the results of the CR value.

$$
C R=\frac{C I}{I R}=\frac{0,03}{0,58}=0,05
$$

Fig. 5. Calculation of $\mathrm{CR}$

Based on the calculation results obtained in Figure 5 the results of $\mathrm{CR}=0.05$, which means $\mathrm{CR}<=0.1$, so it is consistent. The IR value is obtained based on Figure 1 which corresponds to the order of the matrix. Figure 6 is a new hierarchical arrangement added with the weights of each criterion.

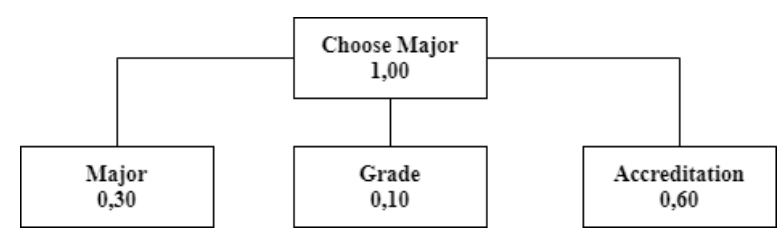

Fig. 6. Hierarchy Added with Weighted Criteria Calculation

\section{E. Calculation of alternative weights}

The next step is to perform calculations for alternative weights. Each alternative performs calculations based on existing criteria. Based on the hierarchy in Figure 7, the weight calculations that must be carried out are alternatives for majors' criteria, alternatives for value criteria, and alternatives for accreditation criteria. Figure 8 is the result of calculating alternative weights based on criteria. 


\section{ISSN 2085-4552}

\begin{tabular}{|c|c|c|c|c|c|}
\hline Major & MIPA-UI & Teknik-UI & Sipil-UI & Elektro-UI & Priority Vector \\
\hline MIPA-UI & 1 & $1 / 4$ & 4 & $1 / 6$ & $(0,13)$ \\
\hline Teknik-UI & 4 & 4 & 1 & $1 / 4$ & 0,24 \\
\hline Sipil-UI & $1 / 4$ & $1 / 4$ & 1 & $1 / 5$ & 0,07 \\
\hline Elektro-UI & 6 & 4 & 5 & 1 & 0,56 \\
\hline Accreditation & MIPA-UI & Teknik-UI & Sipil-UI & Elektro-Ul & Priority Vector \\
\hline MIPA-UI & 2 & 2 & 5 & 1 & $(0,38)$ \\
\hline Teknik-UI & 1 & 1 & 3 & 2 & 0,29 \\
\hline Sipil-UI & $1 / 3$ & $1 / 3$ & 1 & $1 / 4$ & 0,07 \\
\hline Elektro-UI & 1 & $1 / 2$ & 4 & 1 & $0,26)$ \\
\hline Grade & MIPA-UI & Teknik-UI & Sipil-UI & Elektro-UI & Priority Vector \\
\hline MIPA-UI & 1 & 2 & 5 & 1 & $(0,38)$ \\
\hline Teknik-UI & $1 / 2$ & 1 & 3 & 2 & 0,29 \\
\hline Sipil-UI & $1 / 5$ & $1 / 3$ & 1 & $1 / 4$ & 0,07 \\
\hline Elektro-UI & 1 & $1 / 2$ & 4 & 1 & 0,26 \\
\hline
\end{tabular}

Fig. 7. Alternative Calculations

Figure 9 is a new hierarchical arrangement added with criterion weights and alternative weights whose values are obtained from the results of calculations in Figure 8 .

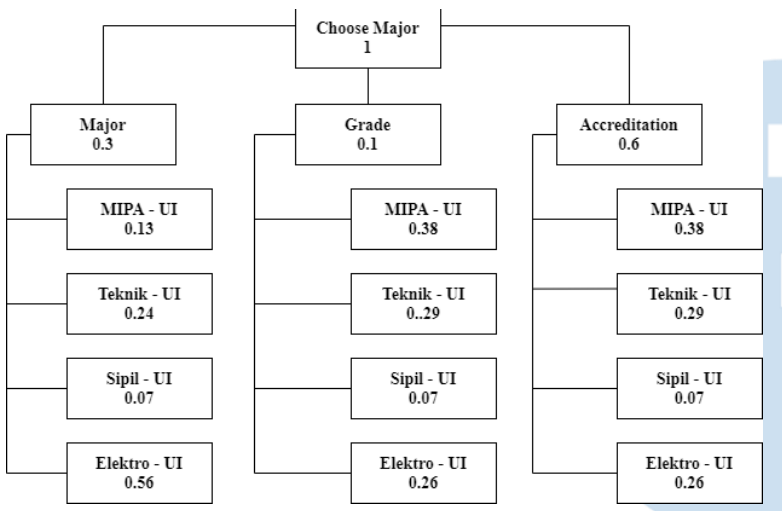

Fig. 8. Hierarchy with Calculated Weights

\section{F. Calculating alternative ranking}

The final step is to calculate the ranking of alternatives. The alternative ranking results are obtained by adding up the multiplication of each alternative weight with the weight of the corresponding criteria. Figure 9 is a calculation to get the ranking results.

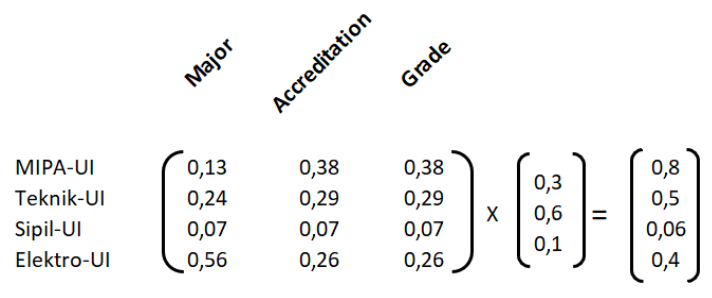

Fig. 9. Alternative Rank Calculations

From Figure 9 it can be concluded that from the calculation of the criteria weights and the alternative weights the ranking results are as follows:

1. MIPA - UI with a result of 0,80 .

2. Teknik - UI with a result of 0,50 .

3. Sipil - UI with a result of 0,06 .

4. Elektro - UI with a result of 0,4
This Academic Information System and Recommendations website is build using Indonesian Language can be accessed by 5 actors: admin, teacher, homeroom teacher, student, and parent. This website provides menus for manage report cards, manage selfdevelopment scores, manage grades, manage attendance, access recommendations, manage recommendations, change passwords, manage exam schedules, download test cards, manage user data, manage grade criteria, register users, manage schedules, manage subjects, manage the school year, manage classes, manage school payment information, view schedules, view report cards, access student grades, and access attendance. Each actor has a different menu access in this website. Figure 10 until Figure 15 shows a snapshot of some of the academic information system interfaces and recommendations that have been made. Figure 10 shows the system view for dashboard.

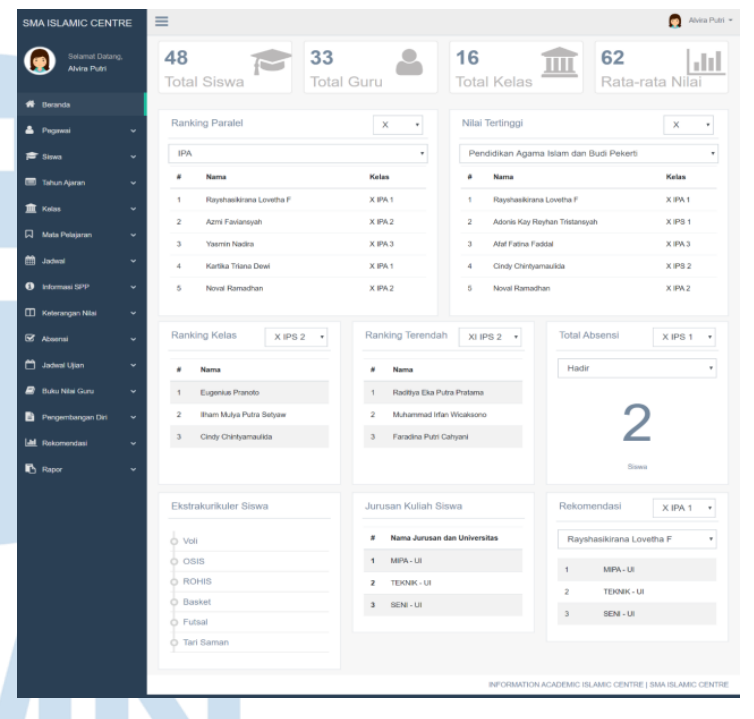

Fig. 10. Dashboard Page

Figure 11 shows the system view for comparison criteria value for recommendations.

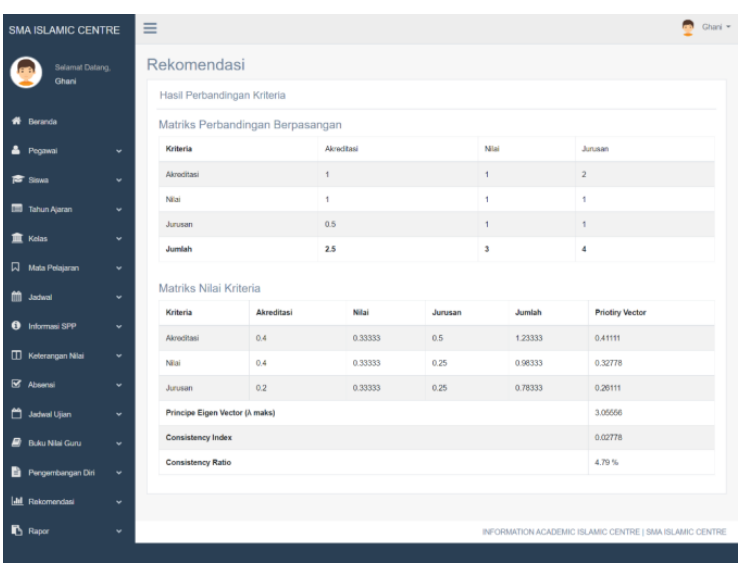

Fig. 11. Comparison Criteria Recommendations Page

Figure 12 shows the system view forrecommendation. 


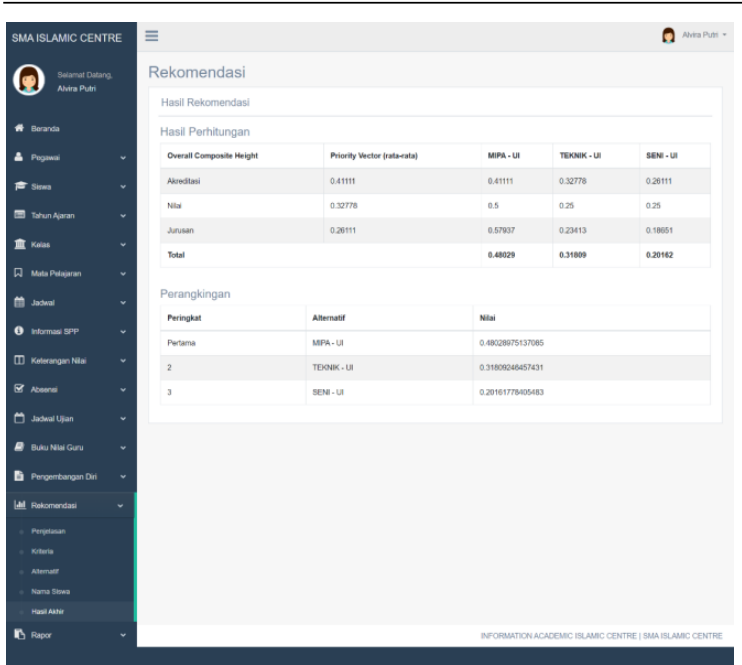

Fig. 12. Recommendations Page

Figure 13 shows the system view for report.

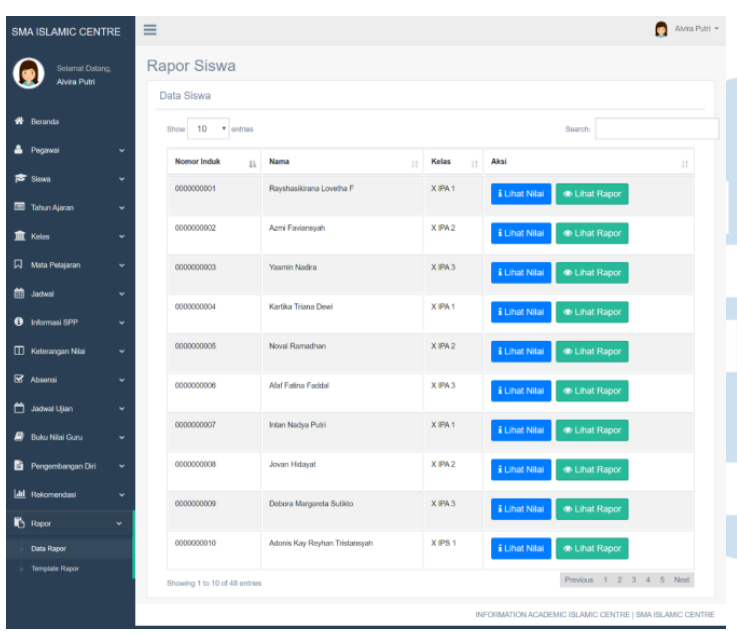

Fig. 13. Report Page

Figure 14 shows the system view for selfdevelopment scores.

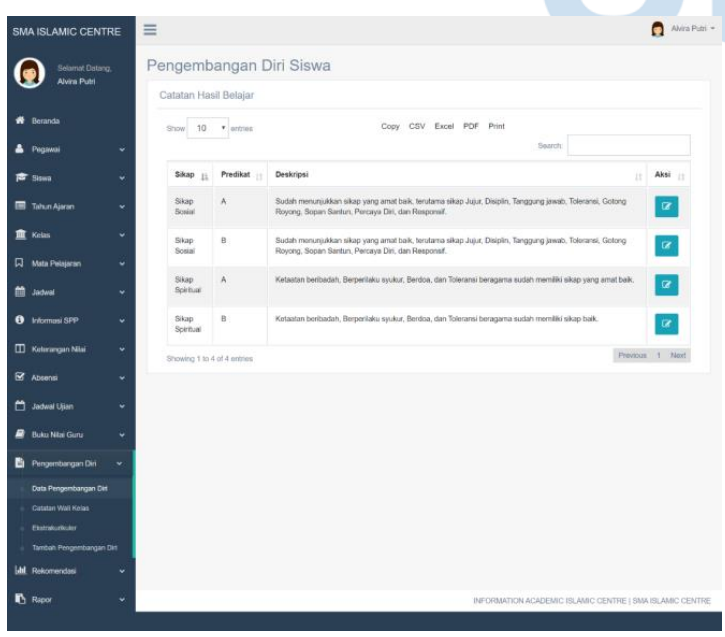

Fig. 14. Self-Development Scores Page

Figure 15 shows the system view for scheduling

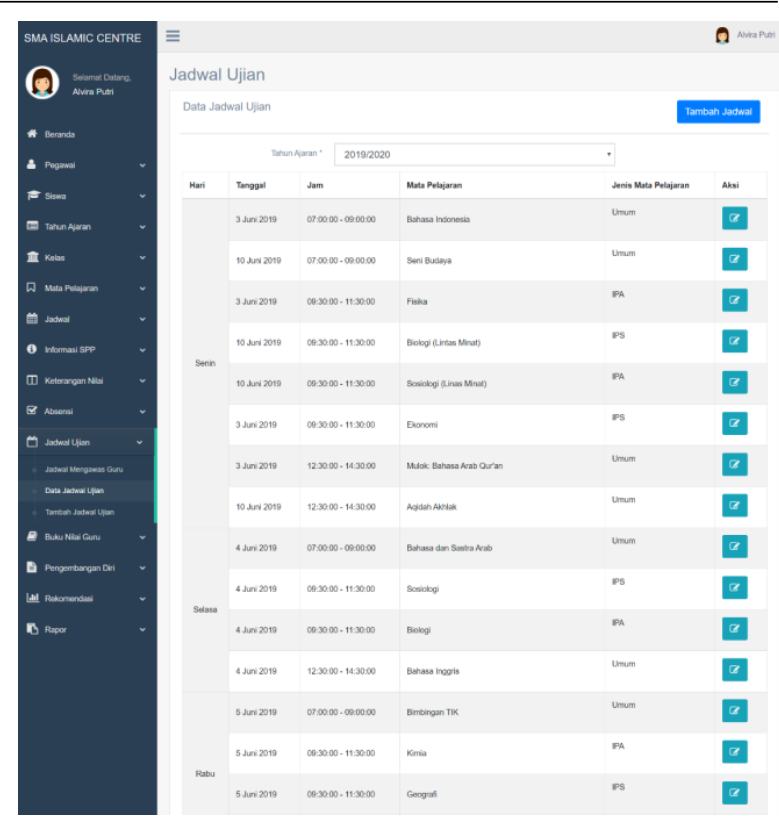

Fig. 15. Scheduling Page

This website uses Blackbox testing method for system functional testing. This website has successfully passed the testing phase on each menu. Table 3 shows an example of Blackbox testing for the criteria comparison page for major recommendations.

TABLE III. BlackboX Testing CRiteria Comparison Page

\begin{tabular}{|l|l|l|c|}
\hline STEP & Test Action & $\begin{array}{c}\text { Expected } \\
\text { Results }\end{array}$ & Status \\
\hline 1 & $\begin{array}{l}\text { Admin } \\
\text { chooses to } \\
\text { create } \\
\text { comparison }\end{array}$ & $\begin{array}{l}\text { System } \\
\text { displays the } \\
\text { comparison } \\
\text { form }\end{array}$ & Pass \\
\hline 2 & $\begin{array}{l}\text { Admin do } \\
\text { comparison } \\
\text { with } \\
\text { determine } \\
\text { past weight, } \\
\text { then } \\
\text { click result }\end{array}$ & $\begin{array}{l}\text { System } \\
\text { displays } \\
\text { result of } \\
\text { comparison } \\
\text { and save it to } \\
\text { database }\end{array}$ & Pass \\
\hline
\end{tabular}

\section{CONCLUSION}

The result of this study is an academic information system for SMA Islamic Center. The conclusions obtained are based on the result of system and Blackbox testing for the user:

- The "Information Academic SMA Islamic Center" system has been successfully designed and developed using the website which can be accessed by homeroom teachers, teachers, homeroom students, students, and admins with different views according to their respective roles.

- The system can also display the grades of each student in the middle of the semester, so that each student can improve their learning for grade 
promotion. The system for viewing report card data can also be printed in PDF form, making it easier for students and homeroom teachers when distributing report cards or when they need a hardcopy of report cards.

- The student data view system can also help each student if there is an incorrect personal data, but not all data can be changed by students, only some data can be changed by themselves. The system also helps students to view the student's class schedule, and the system can also print the student's class schedule.

- Home on the system can help parents/guardians of students in monitoring their children in the field of education. Parents/guardians also get access to see each student's grades.

- Recommendations for majors can be combined with other recommendation methods such as linear regression

\section{REFERENCES}

[1] R. Desanti, C. Supit, and A. Widjaja, "Aplikasi Perekrutan dan Penilaian Karyawan Berbasis Web pada PT. XYZ", Ultima InfoSys : Jurnal Ilmu Sistem Informasi, vol. 8, no. 2, pp. 74-80, Dec. 2017.

[2] X. Wang, "Design and Implementation of College English Teaching Quality Evaluation System Based on Analytic Hierarchy Process," 2020 International Conference on Computers, Information Processing and Advanced Education (CIPAE), 2020, pp. 213-216, doi: 10.1109/CIPAE51077.2020.00062.

[3] F. Fadhilah, "Pengembangan Sistem Informasi Akademik berbasis Web di SMA Negeri 1 Banjarharjo," Yogyakarta, 2016

[4] T. R. Sahroni and H. Ariff, "Design of analytical hierarchy process (AHP) for teaching and learning," 2016 11th International Conference on Knowledge, Information and Creativity Support Systems (KICSS), 2016, pp. 1-4, doi: 10.1109/KICSS.2016.7951412.

[5] M. Susanti, "Perancangan Sistem Informasi Akademik Berbasis Web pada SMK Pasar Minggu Jakarta," Jurnal Informatika BSI, vol. III, no. 1, pp. 91-99, 2016.

[6] Y. Sari, S. D. Ariyanto and S. B. Utomo, "Analysis and Design of Reengineering Academic Information System Astra Polytechnic of Manufacture in Interconnection
Network," 2018 International Conference on Applied Science and Technology (iCAST), 2018, pp. 577-583, doi: 10.1109/iCAST1.2018.8751520.

[7] Nurbojatmiko, A. Fajar Firmansyah, Q. Aini, A. Saehudin and S. Amsariah, "Information Security Awareness of Students on Academic Information System Using Kruger Approach," 2020 8th International Conference on Cyber and IT Service Management (CITSM), 2020, pp. 1-7, doi: 10.1109/CITSM50537.2020.9268795.

[8] F. Suryandani, B. dan D. Maryono, "Pengembangan Sistem Informasi Akademik Berbasis Web sebagai Sistem Pengolahan Nilai Siswa di SMK Negeri 1 Kudus," Jurnal Ilmiah Pendidikan Teknik Kejuruan (JIPTEK), vol. X, no. 1, pp. 71-82, 2017.

[9] T. Sutarsih dan A. N. Hasyyati, "Statistik Penggunaan dan Pemanfaatan Teknologi Informasi dan Komunikasi”, Jakarta: BPS-Statistics Indonesia, 2018.

[10] A. Dennis, B. H. Wixom dan D. Tegarden, System Anlysis \& Design; an Object Oriented Approach with UML fifth edition, Hoboken: John Wiley \& Sons. Inc, 2015.

[11] T. I. Saaty, "Pengambilan Keputusan bagi ParaPemimpin: Hierar-ki Analitik untuk Pengambilan Keputusan dalam Situasi yang Kompleks", Jakarta: Pustaka Binaman Pressindo, 1991.

[12] M. A. Kossukhina, "Modeling of the innovation infrastructure of the university, based on the analytic hierarchy process," 2016 XIX IEEE International Conference on Soft Computing and Measurements (SCM), 2016, pp. 509-511, doi: 10.1109/SCM.2016.7519829.

[13] S. Latifah, "Prinsip-Prinsip Dasar Analytical Hierarchy Process," Studi Kasus Fakultas Pertanian Universitas Sumatera Utara (UsU), pp. 1-5, 2005.

[14] A. M. Syafar, "Sistem Pengambilan Keputusan Memilih Program Studi di UINAlauddin berbasis Web dengan Metode Analytic Hierarchy Process (AHP)," JurnalINSTEK (Informatika Sains dan Teknologi), vol. III, no. 2, pp. 309-318, 2018.

[15] M. Sri, "Riset Operasi", Edisi. Kedua, Jakarta: Lembaga Penerbit Fakultas Ekonomi Universitas Indonesia, 2004.

[16] M. Rahmayu dan R. K. Serli, "Sistem Pendukung Keputusan Pemilihan Jurusanpada SMK Putra Nusantara Jakarta menggunakan Metode Analytical HierarchyProcess (AHP)," Jurnal SIMETRIS, vol. IX, no. 1, pp. 551-564, 2018.

[17] D. Khuntari dan R. Ferdiana, "Sistem Rekomendasi Pemilihan Jurusan PerguruanTinggi dengan Pendekatan User Preference dan Analytic Hierarchy Process,"Seminar Nasional Teknologi Informasi dan Multimedia STMIK AMIKOMYogyakarta, pp. 1-6, 2015

[18] S. Latifah, "Prinsip-Prinsip Dasar Analytical Hierarchy Process," Studi KasusFakultas Pertanian Universitas Sumatera Utara (UsU), pp. 1-5, 2005 